\title{
1, 3, 3, 5-Tetrachloropentane
}

\author{
浅原照三，佐藤 槞，栗田有康 \\ （東京大学生産技術研究所）
$\mathrm{ClCH}_{2} \mathrm{CH}_{2} \mathrm{CCl}_{3}+\mathrm{C}_{2} \mathrm{H}_{4} \longrightarrow \mathrm{ClCH}_{2} \mathrm{CH}_{2} \mathrm{CCl}_{2} \mathrm{CH}_{2} \mathrm{CH}_{2} \mathrm{Cl}$
$\begin{array}{lll}181.9 & 28.1 & 209.9\end{array}$

\section{I. 製 法}

内容 $200 \mathrm{~m} l$ のオートクレーブ（材質 SUS 32, 耐圧常用 $500 \mathrm{~kg} / \mathrm{cm}^{2}$ ，上下電磁カキマゼ型）に 1,1,1,3-tetrachloropropane $100 \mathrm{ml}$ (約 $0.8 \mathrm{~mol}$ ), 严リン酸トリエチル $1.66 \mathrm{~g}(0.01 \mathrm{~mol})$, 無 水塩化第二鉄 (注意 1 ) $0.32 \mathrm{~g}(0.002$ $\mathrm{mol}$ ) を加えて密封し，これに耐圧導管でエチレンボン心゙を連結する。エチレンガスを数気圧まで圧入し放出，この操 作を $5 \sim 6$ 回絽返して内部の空気をエチレンガスで置換する。ついで $30^{\circ} \mathrm{C}$ においてかきまぜながらエチレンガスを 30 $\mathrm{kg} / \mathrm{cm}^{2}$ (注意 2 ) になるまで圧入する。圧入後每分 $5 \sim 6^{\circ} \mathrm{C}$ の割合で昇温させ, $120^{\circ} \mathrm{C}$ に到達したら一度加熱装置の電 流を切り, 温度の上昇に注意しながら再びじょじょに加熱を行ない， $130 \pm 2^{\circ} \mathrm{C} に 3.5$ 時間保つ。オートクレーブを常 温まで泠却した後未反応エチレンガスを放出し, 反応液を取り出して数回水洗する。未反応 1,1,1,3-tetrachloropropane を減圧下留去した後 (tetrachloropropane の変化率約 $40 \mathrm{~mol} \%$ ), さらに減圧にして分留すれば 1,3,3,5-tetrachloropentane (I ) (bp 70 73 ${ }^{\circ} \mathrm{C} / 3 \mathrm{mmHg}$ ) 約 $56 \mathrm{~g}$ が得られる。蒸留残留物はほとんど 1,3,3,7-tetrachloroheptane (II) (約 6 g) である。(I, II の重量比 $90: 10$ )。

\section{II. 注 意 事 項}

(1) $\mathrm{FeCl}_{3}$ に限らず, $\mathrm{FeCl}_{2}, \mathrm{FeCl}_{2} \cdot 4 \mathrm{H}_{2} \mathrm{O}, \mathrm{FeBr}_{3} \cdot 6 \mathrm{H}_{2} \mathrm{O}, \mathrm{FeCl}_{3} \bullet 6 \mathrm{H}_{2} \mathrm{O}$ などの鉄塩も触媒として有効である。お の抢のの鉄塩によってテローダンの変化率，テロマーの組成がいくらか変化する。

(2) エチレン圧によってテローゲンの変化率およびテロマー組成は変化する。反応条件による生成物の組成の変化 については文献1参照。

\section{III. 性質}

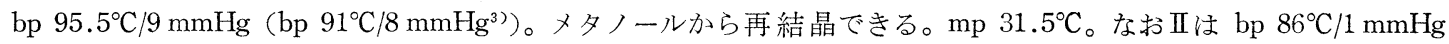
(bp $\left.91^{\circ} \mathrm{C} / 1 \mathrm{mmHg}^{3}\right)$ の液体である。

\section{IV. 本法の利点}

一般的なフリーラジカル系の開始剤では生成物はきわめて複雑な混合物で撰択性がないが，このような触媒を用いる と反応条件により生成物の組成が制御できる ${ }^{1,2)}$ 。なお，イソプロパノールを溶媒とし， $\mathrm{Fe}(\mathrm{CO})_{5}$ を開始剤とした方法 も報告されている3゙。

\section{引用文献}

1) 浅原照三, 栗田有康, 佐藤槞, 工化 741847 (1971)

2) 浅原照三，佐藤璄，栗田有康，生産研究 22169 (1970)

3) E.Ts. Chukovskaya, N.A. Kuzmina, R.Kh. Freidlina, Izv. Akad. Nauk SSSR, Ser. Khim. 1970 2343 